\section{Effects of isolation, daily handling, and enriched rearing on maze learning}

\author{
WILLIAM T. GREENOUGH, THOMAS C. MADDEN \\ and T. BLAISE FLEISCHMANN \\ University of Illinois at Urbana/Champaign, Champaign, Ill. 61820
}

Daily handling for 30 days after weaning reduced straight alley running time in isolated rats, but had no significant effect on Lashley 111 maze learning. Both handled and unhandled isolates were inferior in maze learning to littermates reared in an enriched environment.

It has been known for some time that rats reared in complex social environments are superior to those reared in isolation cages on varjous problem solving tasks (Hebb, 1949; Hymovitch, 1952; Krech, Rosenzweig, \& Bennett, 1962; Rosenzweig, 1966). It has also been found that enriched reared rats differ biologically from isolates in cortical weight and thickness, distribution of some brain enzyme activity, and brain microanatomy (Bennett, Diamond, Krech, \& Rosenzweig, 1964 Rosenzweig, Bennett, \& Diamond, 1972 ; Greenough, West, \& Fleischmann, 1971), as well as in certain indices of stress, such as adrenal weight (Geller, Yuwiler, \& Zolman, 1965). A criticism of the behavioral reports has been that the isolated animals, which have larger adrenals, may react in a different way to $\mathrm{E}$ handling and the test situation, since the rearing environment has not adjusted them to the level of stimulation found in the behavioral task (Melzack, 1969; Myers \& Fox, 1963). Typically, the isolates are handled as little as possible, while the enriched rats are handled daily (Rosenzweig, Bennett, \& Diamond, 1972).

Recently, it has been reported that enriched reared rats show an affinity for their "caretaker" which is not seen in isolated rats (McCall, Lester, \& Corter, 1969; McCall, Lester, \& Dolan 1969 ). This, taken with demonstrations of the interactions between $E$ handling and learning task performance (e.g., Bernstein, 1957), suggests that differential reactions to the $\mathrm{E}$ may contribute to the reported differences in problem solving performance. The present experiment was designed to assess the effects of regular handling on the performance of otherwise isolated rats on a learning task which has been shown to differentiate enriched and impoverished reared animals (West \& Greenough, 1972). Daily handling has previously been found to have little or no effect on the gross brain measures affected by enriched rearing (Krech, Rosenzweig, \& Bennett, 1960).

\section{SUBJECTS AND APPARATUS}

Twelve maie littermate triplet sets of Long-Evans hooded rats (36 individual animals), matched for initial body weight, were weaned and placed inthe differential environments at 22-25 days of age. The testing apparatus consisted of a $1.8-\mathrm{m}$ straight pretraining alley and a $1.2 \times 0.6 \mathrm{~m}$ Lashley III alley maze (Lashley, 1929). All alleys were $10 \mathrm{~cm}$ wide $x$ $13 \mathrm{~cm}$ high and painted gray.

$$
\text { PROCEDURE }
$$

Enriched (EC) rats were reared in a group of 12 in a single cage $(45 \times 60 \times$ $70 \mathrm{~cm}$ ) equipped with a set of toys (homemade and commercially available objects of wood, metal, and plastic), which were changed daily. In addition, they were allowed $30 \mathrm{~min}$ daily free play in a $1.2-\mathrm{m}$-sq field provided with a new set of toys each day. Impoverished (IC) rats were housed singly in $22 \times 25 \times 30 \mathrm{~cm}$ stainless steel cages with wire mesh fronts and bottoms, facing an off-white wall about $1.5 \mathrm{~m}$ away. They had no view of other animals, and were handled for only about $20 \mathrm{sec}$ once each week. Handled (HC) rats were housed identically to the IC rats, except that they were taken from their cages, held, and gently stroked for 2 min each day. Animals were kept on a 7 a.m. to 7 p.m. light schedule at $75^{\circ} \pm 3^{\circ} \mathrm{F}$, with food and water available ad lib until testing began.

After 30 days of the differential environments, Ss were placed on a $23^{3 / 4}$-h water deprivation schedule and were all handled and gentled for 2 days in the manner described above. Ss then began 8 days of training in the straight alley for $0.5 \mathrm{ml}$ water reward (one trial per day, except for one or two extra trials given to four Ss each in the IC and $\mathrm{HC}$ groups on the final day). Over the next 5 days, all rats were trained, one trial per day, on the Lashley III maze. An error was scored whenever a rat's head passed a line
$5 \mathrm{~cm}$ beyond the choice point in one of the blind alleys. Latency from leaving the startbox to entering the goalbox was recorded with a stopwatch. Rats were run in the maze by the same $\mathrm{E}$ who had handled them during the differential environmental period, while errors and time were recorded by a second $E$, who was not told of the treatment condition of the individual animal in the maze.

\section{RESULTS}

Clear differences in straight alley running speed persisted throughout pretraining $(F=5.68, p<.01)$, despite the obvious improvement in all groups across trials (Table 1). Post hoc comparisons (Winer, 1962) showed the $\mathrm{EC}$ and $\mathrm{HC}$ animals to be significantly faster than the ICs $(p<.01)$, while the EC vs HC difference was short of significance $(.05<\mathrm{p}<.10)$. The same pattern holds when the final straight alley trial alone is examined. A rather different pattern is seen, however, in Lashley III maze running time, where the ECs differed from both $\mathrm{HC}$ and IC groups $(F=4.54, p<.05)$, and no significant difference was seen between the two isolated groups ( $F=$ $0.32, p>.25$ ). This pattern continues to hold over the final 4 days of training when running speeds are considerably faster. A similar pattern is seen in the total error data. The groups did not differ significantly on the first maze day (when, of course, they have not seen the location of the goalbox), but the ECs are significantly superior to both isolated groups over the final four trials $(\mathrm{F}=4.21$, $p<.05$ )

These results indicate that the handling of the animals may affect a simple task such as is involved in the pretraining alley in which the performance of the animals depends more upon the tendency to "freeze" for varying periods than upon the ability to learn the task. In the more complex task, however, prolonged freezing was relatively rare, and running speed, after the first trial, tended to parallel the number of errors

Table 1

Mean Daily Latency and Maze Errors for the Differentially Reared Groups

\begin{tabular}{|c|c|c|c|}
\hline & EC & $\mathrm{HC}$ & $1 \mathrm{C}$ \\
\hline Alley & \multicolumn{3}{|c|}{ Running Time (Seconds) } \\
\hline Day 1 & 58.2 & $136.2 \dagger$ & $245.9 *$ \\
\hline Day 8 & 3.3 & 10.5 & $25.7 *$ \\
\hline Maze & \multicolumn{3}{|c|}{ Running Time (Seconds) } \\
\hline Day 1 & 220.7 & 282.8 & 273.8 \\
\hline Days $2-5$ & 28.6 & $52.7^{*}$ & 60.8 \\
\hline & Maze Total & Errors & \\
\hline Day 1 & 8.75 & 8.33 & 7.33 \\
\hline Days $2 \cdot 5$ & 6.33 & $11.42^{*}$ & $11.00^{*}$ \\
\hline
\end{tabular}

*Differs from $E C(p<.05$ or smaller $)$ + Differs from $I C(p<.05$ or smaller $)$ 
on the task. It is possible that, even though the groups were not homogeneous in performance at the end of pretraining, the pretraining adapted them sufficiently to $E$ handling to make them homogeneous in this regard in the maze task. In either case, these results suggest that the behavioral differences reported between enriched and impoverished reared rats following pretraining are not to any great extent due to their reaction to $\mathrm{E}$ handling during training. However, the results also suggest that a handled control might be considered preferable to the typical unhandled IC in tasks involving extensive handling or minimal pretraining. This experiment is one of a series designed to factor out behaviorally the components of the general performance differences between enriched and isolation reared animals. Further studies will examine aspects such as memory formation, attention, and motivation.

REFERENCES

BENNETT, E. L., DIAMOND, M. C.. KRECH, D., \& ROSENZWEIG, M. R.
Chemical and anatomical plasticity of brain. Science, 1964, 146, 610-619.

BERNSTEIN, L. The effect of variations in handling upon learning and retention. Journal of Comparative \& Physiological Psychology, 1957, 50, 162-167.

GELLER, E., YUWILER, A., \& ZOLMAN J. Effects of environmental complexity on constituents of brain and liver. Journa of Neurochemistry, 1965, 12, 949-955.

GREENOUGH. W. T.. WEST, R. W., \& FLEISCHMANN, T. B. Alterations in synaptic parameters produced by rearing environment in rats. Paper presented at first annual meeting, Society for Neuroscience, October 1971.

HEBB, D. O. The organization of behavior. New York: Wiley, 1949.

HYMOVITCH, B. Effects of environmental variations on problem solving in the rat. Journal of Comparative \& Physiological Psychology, 1952, 45, 313-321.

KRECH, D., ROSENZWEIG, M., \& BENNETT, E. Effects of environmental complexity and training on brain chemistry. Journal of Comparative \& Physiological Psychology, 1960, 53, 509-519.

KRECH D. ROSENZWEIG, M. \& BENNETT, E. Relations between brain chemistry and problem solving in rats raised in enriched and impoverished environments. Journal of Comparative \& Physiological Psychology, 1962, 55. 801-807.
LASHLEY, $\mathrm{K} S \mathrm{~S}$ Brain mechanisms and intel ligence. Chicago: University of Chicago Press, 1929.

MCCALL, R. B., LESTER, M. L., \& CORTER, C. M. Caretaker effect in rats. Developmental Psychology, 1969, 1, 771.

MCCALL, R. B., LESTER, M. L., \& DOLAN, C. Differential rearing and the exploration of stimuli in the open field. Developmental Psychology, 1969, 1, 750-762.

MELZACK. R. The role of eariy experience in emotional arousal. Annals of the New York Academy of Sciences, 1969, 159, 721-730.

MYERS, D. R., \& FOX, J. Differences in maze performance of group vs isolation-reared rats. Psychological Reports, 1963, 12, 199-202.

ROSENZWEIG M. R. Environmental complexity, cerebral change, and behavior. American Psychologist, 1966, 21, 321-332.

ROSENZWEIG, M. R., BENNETT, E. L., \& DIAMOND M. C. Brain changes in response to experience. Scientific American, 1972, 226 (2), 22-29.

WEST, R. W., \& GREENOUGH, W. T Effect of environmental complexity on coritcal synapses of rats: Preliminary results. Behavioral Biology, 1972, 7, 279-284.

WINER, B. J. Statistical principles in experimental design. New York: McGraw-Hill, 1962. 